\title{
CAPD による資血改善の効果
}

\author{
大平整爾阿部憲司長山誠 \\ 泉勝子北口和子 川口和子 \\ 岩見沢市立総合病院透析センター \\ (昭和 59 年 8 月 20 日受付)
}

key words：CAPD，貧血，血漿量減少，造血穴進，中分子量物質除去能

〈要旨〉

当院でCAPD を施行した患者は昭和 59 年 4 月末現在 10 名で, 最長 1 年 6 カ月, 最短 2 週間である. 1 名のみ CAPD が慢性腎不全治療の第 1 選択であった以外は残る 9 名全て, 血液透析を一定期間受けた後, 1 ) blood access の荒廃,

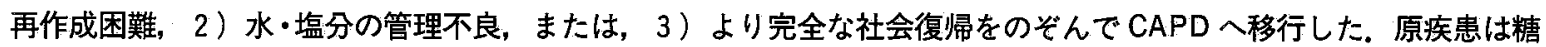
尿病性腎症 2 名, 慢性腎炎 8名であった。

CAPD は Travenol 社のシステム（カテーテルおよび接続チューブ）とダイアニール (透析液) で施行しており， これまで 2 名が繰り返す腹膜炎のためCAPD を中止し血液透析へ復帰している. これら 2 名を含めて全員の賓血改善 の効果は著明であり $\mathrm{Hb}, \mathrm{Hct}$ ともに有意な上昇が認められた。患者の全身状態の改善も自他覚的に明らかであった。 Hb および Hct の上昇は CAPD 開始の初期には溢水の是正，血漿総量の減少によるところがあると推測されたが，以 下の如き CAPD の特性にもとづく要因も大きく作用したものと考えられた.

1) BUN, 血清クレアチニン等小分子量物質の低下，2） methyl guanidine の有意な低下，3） $\beta_{2}$-microglobulin の低下からも推定される中分子量物質の有意な減少，4）水・塩分制限の撤廃による食生活の簡易化と向上，5）各 症例に程度の差はあれ共通していた透析困難症または類似の症状が回避されたことによる心身への好影響，6）鉄代 謝よりみた鉄利用率の向上.

これらが相乗的に作用し CAPD が賓血改善をもたらすものと推定される.

しかし, CAPD 症例にはカテーテルの不調, 腹膜炎などが一定の比率に, しかも特定の患者に頻発しこの場合には Hb, Hct の低下を伴うため注意深いバッグ交換とカテーテル出ロのケアーが心須である.

\section{Improvement in anemia in chronic renal failure patients on CAPD}

Seiji Ohira, M. D., Kenji Abe, M. D., Kazuko Kitaguchi, Kazuko Kawaguchi, Katsuko Izumi, Makoto Nagayama.

Hemodialysis Center, Iwamizawa Municipal General Hospital

Ten chronic renal failure patients were placed on CAPD therapy up to April 1984 in our institution.

An increase in hematocrit (Hct) and hemoglobin $(\mathrm{Hb})$ was a consistent observation in these patients. There was definite subjective and objective improvement in the general condition of the patients. The increase in $\mathrm{Hct}$ and $\mathrm{Hb}$ was thought to be due to a reduction in plasma volume in the early stage of CAPD therapy.

The following factors were considered to have resulted in real hematological improvement ; 1) decrease in BUN and serum creatinine ; 2) decrease in serum methyl guanidine and middle molecular substances responsible for hemolysis and inhibition of erythropoiesis ; 3) qualitative improvement in diet followed from free water and salt intake ; 4) beneficial consequences to both physical and mental condition because fairly common symptoms in each case during hemodialysis were avoided; 5) improved iron metabolism.

It was considered that these factors brought a satisfactory result in ameliorating the anemia in patients

大平 整爾 岩見沢市立総合病院外科

于 068 岩見沢市 9 条西 7 丁目 (01262-2-1650) 
undergoing CAPD.

One must keep in mind that catheter problems and peritonitis are still unavoidable complications in CAPD patients and in these situations $\mathrm{Hb}$ and $\mathrm{Hct}$ decrease.

\section{はじめに}

慢性腎不全のため血液浄化療法を受けている患者の貧 血は近年著しく改善1)しているとはいえ，いぜん大きな 問題の 1 つして残っている. 私どもは種々な理由から CAPD へ導入した患者に著明な貧血の改善を認めたた め, その背景因子に若干の検討を加えここに報告する。

\section{対象・方法}

当院でCAPD へ導入した症例（表 1) を対象とし定期 的に検査された血液生化学值, 体重, 心胸比などを分析 した. 10 名中 1 名で CAPD が慢性腎不全治療の第 1 選 択である以外，残る 9 名は全て血液透析を一定期間受け たのち，1) blood access の荒廃, 再作成困難, 2 ) 水・ 塩分管理の不良，または 3 ）より完全な社会復帰などの ためCAPDへ移行した。腎摘出術を受けた者はいない. 糖尿病性腎症が 2 名のほかは全て慢性腎炎を原疾患と し, CAPD 開始時の年齢は $30 \sim 52$ 歳と比較的若い世代 であった。

\section{CAPD 施行法}

シングルカフのテンコフフ式カテーテルを留置後 4 日間 はダイアニール $1.5 \%$ 糖液を $500 \sim 1,000 \mathrm{~m} l /$ 回注液し, 1 日. $4 \sim 6$ 回のバッグ交換を行った。 その間, 血圧上昇 または体重增加がその時点での至適体重の $5 \%$ を越えた
場合, 1 回 5 時間の血液透析を行った. その後, ダイア ニール $1.5 \%$ 糖液 $1,500 \mathrm{~m} l /$ 回注液, 1 日 4 回のバッグ交 換を $2 \sim 3$ 日間施行し次いで注液 $2,000 \mathrm{~m} l$ /回, バッグ交 換 4 回/日とし原則として 1 日 1 回ダイアニール 4.25\% 糖液を使用した。 $2,000 \mathrm{~m} l /$ 回の注液となった後, 食事は 自由とし，原則として水分，塩分の制限をなくした。

\section{CAPD 施行後の定期投薬および輸血}

ほほ全例に投薬していた蛋白同化（ホルモンハロテス

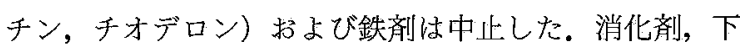
率, ビタミン剂， $\alpha$-ロール®，アルミゲル®，ザイロリッ ク®等は症例によっては投与している。血清カリウムが $3.5 \mathrm{mEq} / l$ 以下の低値を示す 5 症例にはアスパラ $\mathrm{K}^{\circledR} 3$ 〜 錠/日を内服せしめた. 糖尿病性腎症 2 名中 1 名がイ ンスリンを必要としており当初インスリンのバッグ内注 入としたが軽い腹膜炎を合併し，以降，患者の希望もあ り自己皮下注射に切りかえている. CAPD 開始後, 輸血 を行った症例は皆無である.

\section{結果}

1. Hct, $\mathrm{Hb}$ の変化

$\mathrm{Hb}$ は Hct との間に正の相関 $(\mathrm{r}=0.9654)$ をみたので Hct の変化についてデーターのそろった 7 症例について 検討した。腎移植後, 慢性拒絶反応に宿った症例 4

\begin{tabular}{|c|c|c|c|c|c|c|c|c|c|c|}
\hline No. & 患者名 & 性 & 年齢 & \multicolumn{4}{|c|}{ 透 } & \multirow{2}{*}{$\begin{array}{l}\begin{array}{l}\text { CAPD } \\
\text { 開始日 }\end{array} \\
57.11 .18\end{array}$} & \multirow{2}{*}{$\begin{array}{l}\text { CAPD 移行の理由 } \\
\text { Blood access } \\
\text { 作成困難 }\end{array}$} & \multirow{2}{*}{$\begin{array}{l}\text { 備 考 } \\
\text { 外 来 }\end{array}$} \\
\hline 1 & & 女 & 33:歳 & \multicolumn{2}{|c|}{$45.6 \sim 56.11$} & I.P.D & $56.11 \sim 57.11$ & & & \\
\hline 2 & & 女 & 30 & \multicolumn{2}{|c|}{$56.9 \sim 56.10$} & H.D & $56.10 \sim 58.3$ & 58.3 .11 & 水・塩分管理不良 & 外 来 \\
\hline 3 & & 女 & 39 & \multicolumn{2}{|c|}{$48.7 \sim 49.2$} & H.D & $49.2 \sim 58.3$ & 58.3 .29 & $\begin{array}{l}\text { Blood access } \\
\text { 作成困難 }\end{array}$ & 59.2 .3 中止* \\
\hline 4 & & 男 & 29 & $\begin{array}{l}\text { I.P.D } \\
48.11 \sim 48.12\end{array}$ & $\begin{array}{l}\text { H.D } \\
48.12\end{array}$ & 56.1 & $\begin{array}{l}\text { 腎移植 } \\
56.1 \sim 58.4\end{array}$ & 58.4 .7 & 社会復㷌 & 59.2 .6 中止* \\
\hline 5 & & 男 & 49 & \multicolumn{4}{|c|}{$58.2 \sim 58.8$} & 58.8 .24 & 社会復帰 & 外 来 \\
\hline 6 & & 男 & 32 & \multicolumn{4}{|c|}{$52.10 \sim 58.9$} & 58.9 .5 & $\begin{array}{l}\text { Blood access } \\
\text { 作成困難 }\end{array}$ & 58.11 .18 死亡 \\
\hline 7 & & 男 & 50 & \multicolumn{4}{|c|}{$58.11 .28 \sim 59.1 .12$} & 59.1 .13 & 社会復帰 & 糖尿病 - 外来 \\
\hline 8 & & 男 & 51 & \multicolumn{4}{|c|}{$54.1 .10 \sim 59.4 .16$} & 59.4 .17 & 社会復帰 & 入 院 \\
\hline 9 & & 男 & 52 & \multicolumn{4}{|c|}{$58.12 .13 \sim 59.1 .22$} & 59.1 .24 & $\begin{array}{l}\text { Blood access } \\
\text { 作成困難 }\end{array}$ & 糖尿病・入院 \\
\hline 10 & & 女 & 50 & & 59.4 .23 & 社会復㷌 & 入 院 \\
\hline
\end{tabular}

H.D : 血液透析, I.P.D : 間歇的腹膜透析，* : 腹膜炎

表 1 CAPD 症例（岩見沢市立, 昭和 59.5 現在) 


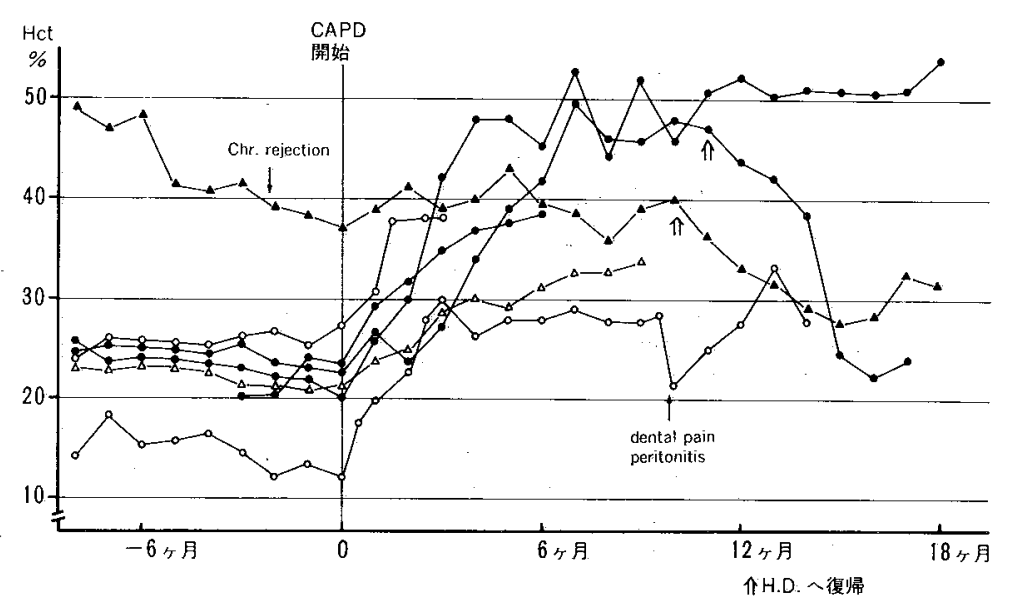

図 1 CAPD 開始前後の Hct の変化 $(\mathrm{n}=7)$

を除いて他の 6 例の Hct はいずれも $3 \sim 6$ カ月間, 急上 昇しその後, 上昇率は低下している。

症例 4 を除いて CAPD 開始時 Hct $21.6 \pm 5.2 \%$ (平均 $\pm \mathrm{SD}$ ), $\mathrm{Hb} \quad 5.94 \pm 1.41 \mathrm{~g} / \mathrm{d} l(\mathrm{n}=6)$ であり一方 $\mathrm{CAPD}$ 開始 6 力月後の Hct は $37.3 \pm 8.4 \%, \mathrm{Hb} 10.98 \pm$ $2.60 \mathrm{~g} / \mathrm{d} l$ で $\mathrm{p}<0.01$ の危険率で有意の上昇がみられた。 1 年 6 カ月血液透析を継続し血清クレアチニン ( $\mathrm{S}-\mathrm{Cr}$ ) 10〜 $12 \mathrm{mg} / \mathrm{d} l$, BUN 30〜 $50 \mathrm{mg} / \mathrm{d} l$ でありながら Hct が 常に $18 \%$ 以下であった 30 歳女子（症例 $2 ：$ ）にみ られた自覚的 well-beings の向上を伴う著明な貧血改善 が特徽的であった（図 1 ). 一方, 症例 3 では 約 10 年間の血液透析期間中 Hct は 20 28\%であった が, CAPD 開始後, 急上昇し 6 力月後には $48 \%$ に達した。 この症例はその後, 腹膜炎を繰返したため CAPD を中止 し Hctは急速に低下して再び 22〜24\%にもどっている. CAPD をやはり中止した症例 4

でも Hct の低

下が認められた。

\section{2. $\mathrm{S}-\mathrm{Cr}$ 朽よび BUN の変化}

間歇的腹膜透析（週 3 回, ペリトゾール $10 l /$ 回）の症 例 1 , 单針透析 (SND) の症例 6 は CAPD 開始後, S-Cr の著明な減少がみられた(図 2). その他の症例でも CAPD 開始後 S-Cr の上昇はみられ ずむしろ減少の傾向を示している. BUN は腎移植後の 慢性拒絶反応を呈した症例 4 を除いて CAPD 開始時 $56 \sim 108 \mathrm{mg} / \mathrm{d} l$ のレベルにあった。

CAPD 開始後, 図 2 に示したように有意に減少した。 図 2 でみる BUN の急上昇は症例 2 では腹膜炎 発症時であり症例 3 では CAPD を中止して SND 復鹵したためである. Urea-N, creatinine の週
1）十分な透析：BUN, S-Cr の低下

2) 血液透析時にみられた各種症状, 血液喪失の回避

3）食生活の改善

4) 中分子量物質, グアニジン誘導体など（溶血六進または 骨梿機能抑制因子）の減少

表 2 CAPD による貧血の改善

当りクリアランスは血液透析 (週 3 回, 計 15 時間) に比 較して 65〜 70\% ${ }^{2)}$ ではるが，実際にはBUN，S-Cr は 上昇せずむしろ減少しだ)。

3 . 体重および血圧, 心胸比

CAPD 開始時の体重を基準として本法施行後の体重 の変化率（\%）を図 3 に示した。

カテーテル插入後, 注液を開始し 1 週間は大半の症例 で体重が減少し, この間, 脱力感と血圧低下が認められ た。 その後, 透析液の注入・排出による腹満感や異和感 に慣れてくると食事捸取も円滑になり体重は徐々に増加 してくる. 本法開始後 3 例では 1 力月で開始時の体重を 越えているが, 血圧はむしろ低下し, 心胸比に変化なく $50 \%$ 以下であった. CAPD 開始後 6 力月では 1 例が開始 時の体重であるほか, 全て $2 \sim 3 \%$ 増加している。 6 力 月以降も体重は漸増するが私どもの症例では+ $5 \sim 6 \%$ 止りであり，症例 2 が 1 年 2 力月を経て 43.2 $\mathrm{kg}$ から $50.3 \mathrm{~kg}$ と約 $7 \mathrm{~kg}$ 体重増加で肥満傾向を示し た。

しかし, いずれの症例も体重増加に伴って血圧の上昇 や心胸比の増加はみられなかった。

4. 血中 $\beta_{2}$-microglobulin $\left(\beta_{2}-\mathrm{MG}\right)$

分子量 11,800 の $\beta_{2}-\mathrm{MG}$ は無尿症例のクプロファン膜 


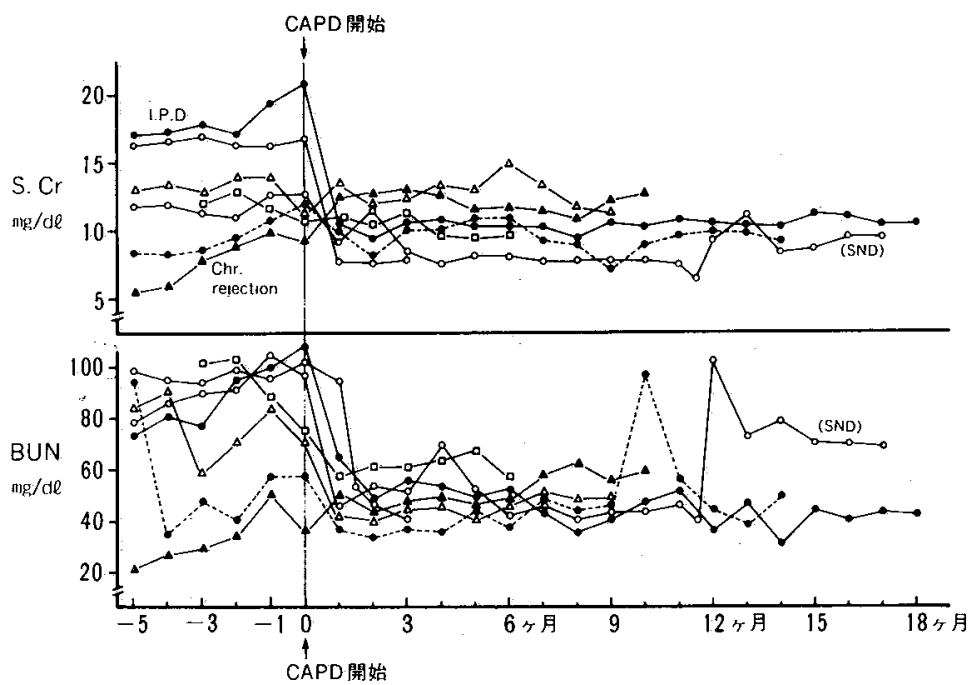

図 $2 \mathrm{CAPD}$ 開始前後の S-Cr, BUN の変化 $(\mathrm{n}=7)$

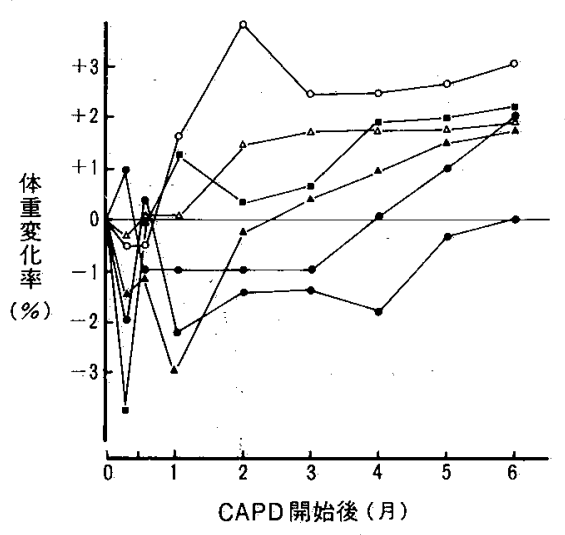

図 $3 \mathrm{CAPD}$ 開始後の体重変化率

透析では経年的に増加の傾向 ${ }^{4)}$ をすが，CAPD 開始後 は比較的早期に低下の傾向を示した（図 4).

5. Hct と血清 methyl guanidine $(M G)$

中尾ら ${ }^{5}$ は血清の MG が CAPD 症例でHD, $\mathrm{HDF}$, IPD の症例に比較して有意に低いことを報告している。 私どもの症例も同様の傾向を示し,さらに Hct と $\mathrm{MG}$ の間には負の相関がみられた（図 5 ).

6. 血清トリグリセライド（TG）とコレステロール

TG については Nolph らの報告 ${ }^{6}$ のような有意の上昇 は認めなかったが, 血清コレステロールでは增加の傾向 がみられた（図6).

7. 血清鉄, フェリチンおよびトランスフェリチン 血清フェリチンは CAPD 開始時, 血液透析期間, 輸血 量，静注鉄剤投与量などに影響されてさまざまの值を示
した。しかし，CAPD 開始後，血清フェリチン高值は辢 次, 是正され一方, 血清トランスフェリンは漸増して蛋 白代謝異常の改善が示唆された。いずれにせよ, 腎性貧 血治療上，有利な変動と考えられた。血清鉄もCAPD 開 始時, 高・低值種々であったが，しだいに $110 \sim 140 \mu \mathrm{g} /$ $\mathrm{d} l$ と正常域の值をとるにいたった(図 7)。これらから鉄 利用率の上昇が推測された.

\section{考案}

血液透析患者の貧血状態は，1）末期腎不全患者の管 理の合理化とそれに伴う血液透析導入時期の適正化, 2) ダイアライザー, 透析技術の進歩, 消毒法の変更, 3) 水処理方法の改善, 4) 血液透析量, 透析回数の増加, 4) 輸血施行基準の厳格化，5)食事療法に関する知識 の向上と体験化，6）貧血是正に対する各種補助療法の 併用などによって, 近年, 著しく改善されてきている1. しかし, 一部の血液透析患者では血液透析の継続にもか かわらず Hct $20 \%, \mathrm{Hb} 5.0 \mathrm{~g} / \mathrm{d} l$ 内外と高度の貧血状態 がみられ，貧血はいぜん血液浄化療法を受ける患者に とって重大な問題の 1 つである.

過去数年間に, CAPD 療法が急速に普及しこの方法に よって貧血が著明に改善したとする報告が多くみられ $る^{3,5,7 \sim 10)}$. 私共の CAPD 症例の経験はいまだ少数にとど まっているが, CAPD 開始後の貧血改善を臨床的に実感 している.

さて, 多くの報告や私共も貧血改善の基準を Hct, $\mathrm{Hb}$ の上昇に扔いている。しかし， Hct， Hb ともに循環血液 量の增減に影響を受けるものである.このため, plasma volume の変化に左右されない指標として red cell mass 


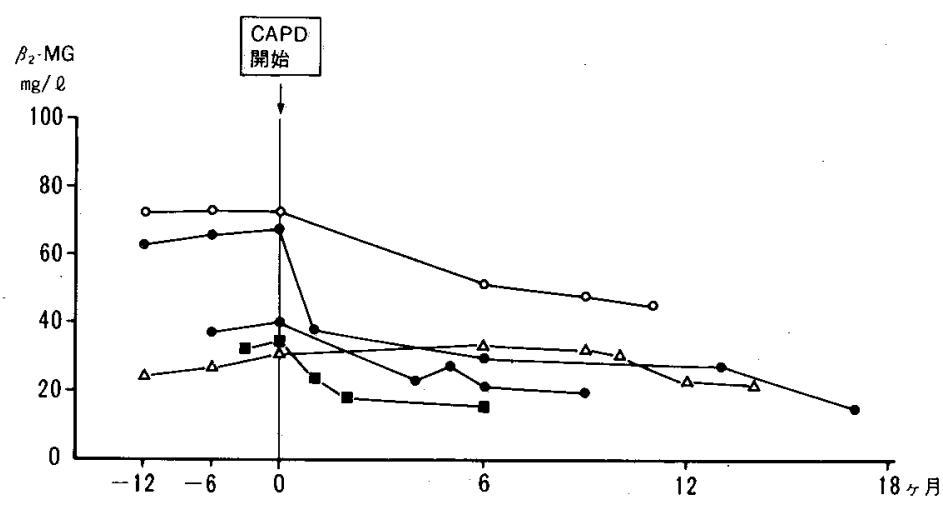

図 $4 \quad \beta_{2}$-Microglobulin の変化

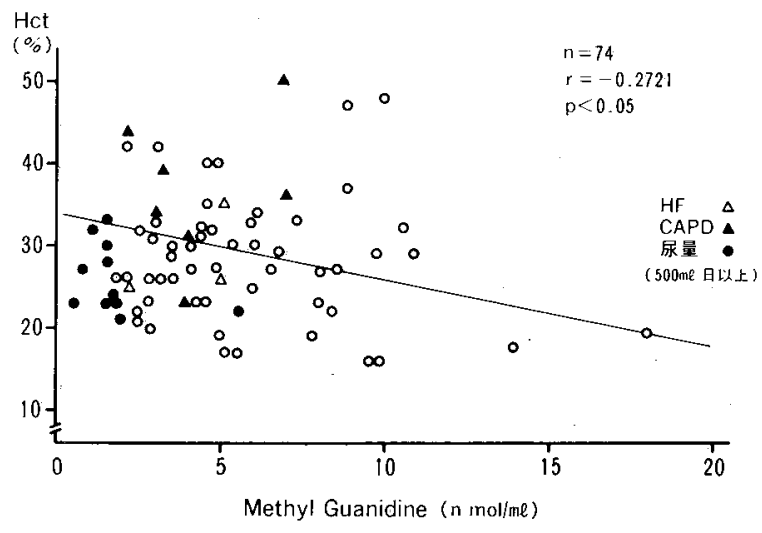

図 5 透析患者の Hct と Methyl Guanidine

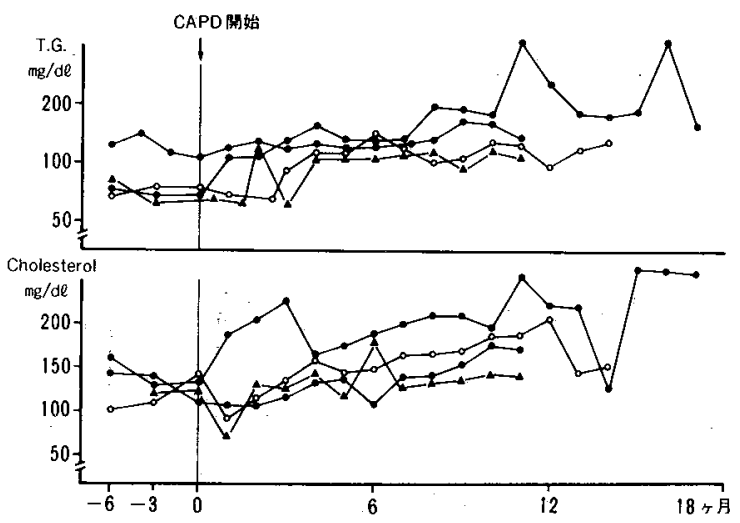

图6 TG \& Cholesterol

$(\mathrm{RCM})^{11)}$ が CAPD 前後に如何に変動するかが検討され ている. DePaepe ら (1981) ${ }^{12,13)}$ は自家赤血球に ${ }^{99 \mathrm{~m}} \mathrm{Tc}$ をラベルして 49 名の CAPD 患者においてこれを検查 し, CAPD 開始後 6 力月目に plasma volume が減少し

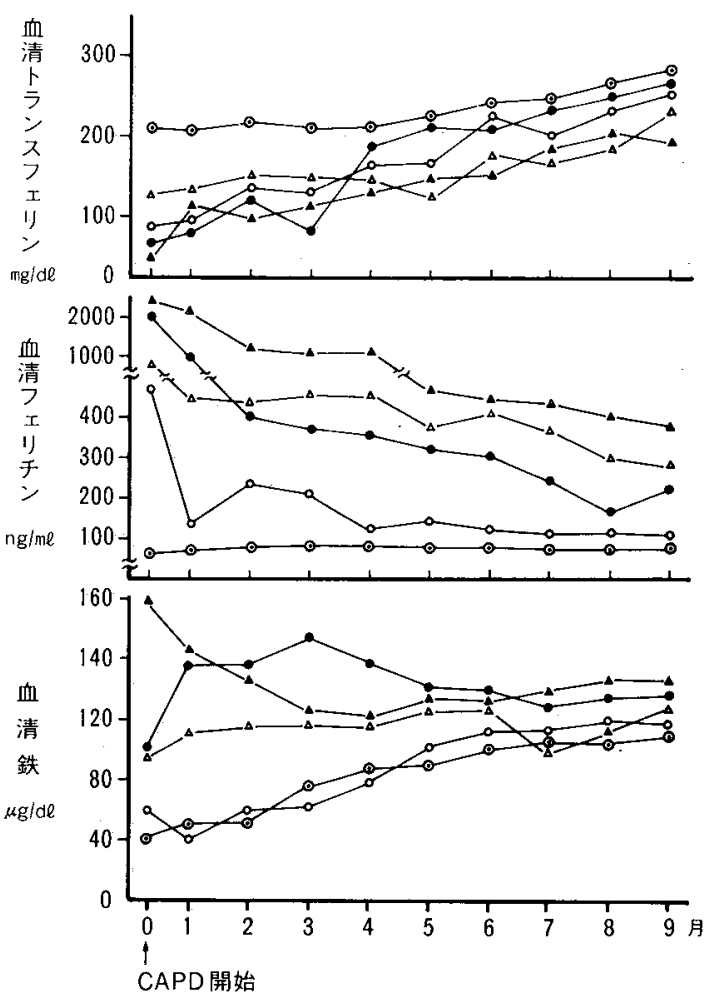

図 7

1 年目には RCM が上昇していたと報告している.一方， Mehta ら (1983) ${ }^{14)}$ は ${ }^{51} \mathrm{Cr}$ ラベル自家赤血球と ${ }^{125} \mathrm{I}$ 一七 トアルブミンを用いて 10 名の CAPD 患者の RCM; plasma volume を測定し CAPD 開始 6 力月目両者に有 意な変化はなく，12 力月目に plasma volume の有意な 減少をみたとしている。

De Paepe ら, Mehta らの CAPD 症例はいずれも 6 カ月， 12 力月目で Hct が有意に上昇している。このよ 
うに，De Paepe らは CAPD による RCM の増加を認め

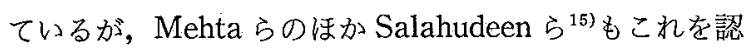
めず CAPD による Hct の上昇には CAPD による細胞 外液の有意な減少と血液透析に比較して血液变失の少な いことが作用していると述べている，血液透析によって 除水が通常の如く行れた場合, 自験例の血液透析前後で Hct は図 8 のように除水量（体重隇少）によく相関して 上昇するが，短時間で plasma re-filling が追いつかな いためと考元られる。すなわち, plasma volume の減少 を主因とする Hct の上昇である ${ }^{16)}$. 私共は RCM, plasma volume を放射性同位元素で測定していないが， CAPD 開始後 2 カ月前後までは体重が図 3 のように減 少する症例が半数でありこの間これらの症例では血圧低 下と脱力感を継続して訴兄, 循環血液量の減少がつよく 推定された.

CAPD が血液透析よりも細胞外液量を効果的に減少 せしめることが, CAPD 開始後初期の Hct 上昇に大き く影響していようが, その後の体重増加, 自覚的な well -beings の向上などからは, CAPD 施行による実質的な Hct の上昇, 造血六進効果も確かにあると推測される ${ }^{17}$. CAPD による主として Hct の上昇から貧血改善を報告 する論文が多いなかで Hct が不変であったとする論文 も散見される ${ }^{15,18,19)}$.

このような結果の不一致は CAPD へ導入される患者 の広義の造血機構にかなり大きな差違が存在するためで あろう。例えば，Zappacosta $\check{~}^{20)}$ は CAPD 9例を 1 年 以上観察し Hct の上昇した 4 例の血清エリスロポエチ ン值が $9.0 \mathrm{mU} / \mathrm{m} l$ 以上 (平均 $28 \mathrm{mU} / \mathrm{m} l$ ), Hct の上昇 しなかった 5 例の同值が $5 \mathrm{mU} / \mathrm{m} l$ 以下 (平均 $3 \mathrm{mU} / \mathrm{m} l$ ) と明らかに前者の血清エリスロポエチン值が高かったと 報告している。

しかし, McGonigle ら ${ }^{21)}$ は CAPD 症例の Hct は血液 透析症例の Hct よりも有意に高いが両群の血清エリス ロポエチン值に有意差を認めていない. Hct 值はいずれ の治療群でも血清エリスロポエチン值とは相関せず CFU-E (colony forming unit-erythroid) の程度と正の 相関を示した。この点から, 現時点で CAPD が血清エリ スロポエチン産生を促進するというデーターは得られて おらず CFU-E を規制する造血抑制物質と推定される中 分子量物質の除去能が CAPD で大きいことが, 有意に 高い Hct を招くものと考元られ. Lamperi ら ${ }^{22)}$ CAPD の患者に著明な貧血改善を認め, これは CAPD によって血液透析時に比較して peak $7 \mathrm{cl}^{23)}$ の除去能が 穴進し,このため骨䯣抑制物質が隇少, CAPD が貧血改 善に働くためとしている.

Moncrief ら ${ }^{24)}$ はでに 1979 年, CAPDでは血液透析

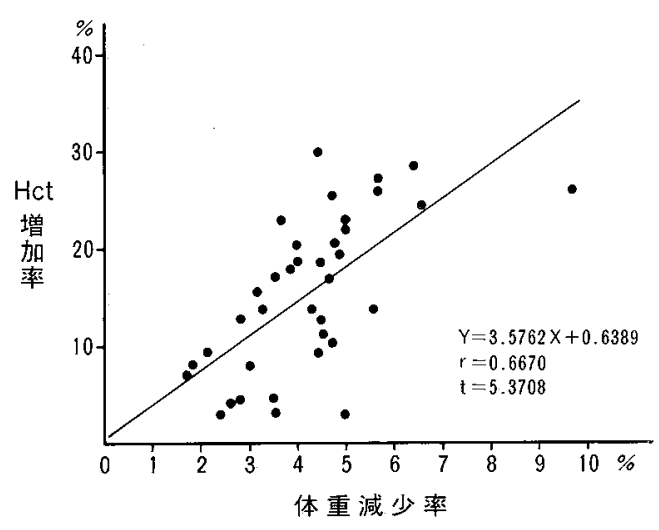

図 8 血液透析による除水と Hct の上昇

に比較して中分子量物質の体内からの除去量が週当り 5 〜6倍も多いことを示したが, 一方, 中尾ら ${ }^{5}$ は CAPD 患者では他の血液净化法を受ける患者に比較して実際に 血清中分子量物質, 血清 $M G$ の濃度が低下することを報 告している.これまでのところ, CAPDへ導入された症 例は blood access のトラブルを有するか, 血液透析中 に著しい症状を呈するかまたは心肺機能の低下した場合 が多く, 侵襲性の少ない CAPDの開始によって BUNゃ S-Cr は低下傾向を示す.私共の症例でも間歇的腹膜透析 や単針血液透析症例では CAPD の開始によって BUN, $\mathrm{S}-\mathrm{Cr}$ ともに著明な減少がみられ，これも $\mathrm{Hct}, \mathrm{Hb}$ 上昇 の一因となっていると考光られた。溶血充進物質として はグアニジン化合物よりも尿素窒素やクレアチニンの方 が強い作用を有することが認められているからであ $る^{5)}$. 血液透析に伴う各種症状やダイアライザー内の残 血その他の血液敨失が CAPD の開始とともに回避され て貧血の改善に直接的，間接的に有利に働くことも明ら かである。

CAPD の開始, 約 2 週間後に水分・壏分の制限をなく しているが，このため食生活が容易となって質的な向上 も見られた。

糖尿病性腎症を除く 6 例でダイアニール $1.5 \%$ 糖液 2 $l, 3$ 回/日, $4.25 \%$ 糖液 $2 l, 1$ 回/日の CAPD を行った 場合の糖吸収量を排液の糖濃度から算出したところ $127.8 \pm 15.7 \mathrm{~g}$ (平均 $\pm \mathrm{SD}$ ) であった ${ }^{25)}$ 。これは透析液 中の糖の約 $73 \%$ が吸収されたことを示し吸収された糖 は約 $512 \mathrm{kcal} /$ 日にも達する。非窒素性のエネルギー源と して protein sparing には有利に作用するものと考えら れる。'.

腹膜自体の生理学的特性から CAPD では中分子量物 質, グアニジン誘導体など血液透析に比較して分子量の 大きい物質の除去能が大きく, CAPD の継続によってこ 
れら物質の血中濃度が有意に低下することは既述のごと くであり，このため溶血や骨髄抑制が緩和されるものと 推定される。このようにCAPDによる貧血の改善 (Hct, $\mathrm{Hb}$ の上昇)には開始当初, 有効な除水による血漿量の減 少が一因とはなっているが, その後, 表 2 の諸因子が相 乗的に働いているものと考えられる.

十分な透析による BUN, S-Cr の一層の低下, 血液透 析に伴う各種症状の軽隇は血液透析やその変法について 様々な工夫を行うことによっても可能なことがある。し たがって，これらを CAPDにのみ期待する必要はない。

また，血液透析を受けている患者にも充実した食生活 を続ける者も多い.しかし，これらの諸点を血液透析を 行いつつ改善することは私共の実感としては $20 \%$ 内外 の血液透析患者では極めて困難である。したがって，表 2 の項目 1，2，3 は CAPD 療法に特徴的なこととは必ず しも断定しえないにしろ，CAPDでは比較的容易に達成 しうるために透析患者の貧血改善上, CAPD に有利な点 と言える。

\section{おわりに}

$\mathrm{CAPD}$ による Hct， Hb の上昇は，本法開始初期には 循環血漿量の隇少がかなり大きく影響しているが, BUN, S-Cr の低下, 食生活の向上, 血液培失の回避やさ らに本法の最も特徴的な点と考元られる中分子量物質や グアニジン化合物などの除去能の增大によって真の貧血 改善が期待しうるものである。

本論文の要旨は第 29 回人工透析研究会総会 (昭和 59 年 7 月，京都にに扔いて発表した。

\section{文献}

1）大平整爾, 阿部憲司, 今 忠正：血液透析患者の貧 血一臨床面加の問題点と対策一, 透析会誌, 15 ： 9-20, 1982.

2) Drukker, W. : Peritoneal Dialysis, Replacement of Renal Function by Dialysis (2 nd ed.) ed by Drukker, W., Parsons, F. M., Maher, J. F., pp 410 -439, Martinus Nijhoff Publisher, Boston, 1983.

3）太田和夫：持続的外来腹膜透析 (CAPD). 日本臨牀 (特集) 維持透析，39：273-284，1981.

4）大平整爾, 阿部憲司, 長山 誠：慢性血液透析患者 の血清 $\beta_{2}$-microglobulin の臨床的検討. 腎と透析, $13: 813-818,1982$.

5）中尾俊之, 小林正之, 藤原誠治, 宮原 正：透析患 者の貧血の成因における uremic toxins の関与. 透 析会誌 $15 ： 273-280,1982$.

6) Nolph, K. D., Sorkin, M., Rubin, J., Arfania, D.,
Prowant, B., Fruto, L., Kennedy, D. : Continuous Ambulatory Peritoneal Dialysis: Three-Year Experience at One Center. Ann. Int. Med., $92: 609$ $-613,1980$.

7) Popovich, R. P., Moncrief, J.W., Nolph, K. D., Ghods, A. J., Twardowski, Z. J., Pyle, W.K. : Continuous ambulatory peritoneal dialysis. Ann. Int. Med., 88 : 449-456, 1978.

8) Goldsmith, H. J., Forbes, A., Gyde, O. H. B. : Hematologic aspects of continuous ambulatory peritoneal dialysis, Continuous Ambulatory Peritoneal Dialysis (ed. by Legrain, M.), Excerpta Medica, pp 302-308, Amsterdam, 1980.

9) Oreopoulos, D. G. : The coming age of continuous ambulatory peritoneal dialysis, Dial. Transpl., 8 (5) : 460-461, 1979.

10) Katirtzoglou, A., Oreopoulos, D. G., Dombros, N., Pierratos, A., Pantalony, D. : Hematologic state of patients undergoing continuous ambulatory peritoneal dialysis (CAPD), Kidney Int., $15: 712$, 1979.

11) Wintrobe, M. M., Lee, G. R., Boggs, D. R., Bithell, T. C., Athens, J.W., Foerster, J.: The Erythrocyte, Morphology, Intrinsic Metabolism, Function, Laboratory Evaluation. Clinical Hematology Chapter 3, pp 80-124, Lea \& Febiger, Philadelphia, 1974.

12) DePaepe, M., Lameire, N., Schelstraete, K., Ringoir, S. : Chages in red cell mass, plasma volume, and hematocrit in patients on continuous ambulatory peritoneal dialysis. Proc. EDTA, $18: 286$ $-289,1981$.

13) DePaepe, M. B., Schelstraete, K. H., Ringoir, S. M., Lameire, N. H. : Influence of continuous ambulatory peritoneal dialysis on the anemia of end stage renal disease. Kidney Int., $23: 744-748,1983$.

14) Mehta, B. R., Mogridge, C., Bell, J.D. : Changes in red cell mass, plasma volume and hematocrit in patients on CAPD. Trans. Am. Soc. Artif. Intern. Organs, $24: 50-52,1983$.

15) Salahudeen, A. K., Keavey, P. M., Hawkins, T., Wilkinson, R. : Is anemia during continuous ambulatory peritoneal dialysis reallybetter than hemodialysis ? Lancet, 2(8358) : 1046-1049, 1983.

16）安部 英, 中村一路: 維持透析の医学的問題点, 血 液学的異常. 日本臨彇, $39: 191-204,1981$. 
17）中川成之輔 : CAPD, Continuous Ambulatory Peritoneal Dialysis. 人工臟器, $12: 854-861.1983$.

18) Marcovici, O., Boner, G., Rosenfeld, J. B. : Effect of continuous ambulatory peritoneal dialysis on anemia in uremic patients. ISR J. Med. Sci., 19 : 604-607, 1983.

19) Spinowitz, B. S., Sherwood, J., Galler, M., Charytan, C. : Anemia and oxygen affinity in patients on continuous ambulatory peritoneal dialysis. Peritoneal dialysis bulletin suppl., 3(1) : 33-35, 1983.

20) Zappacosta, A. R., Caro, J., Erslev, A. : Normalization of hematocrit in patients with end-stage renal disease on continuous ambulatory peritoneal dialysis, The role of erythropoietin. Am. J. Med., 72 : 53-57, 1982.

21) McGonile, R. J.S., Husserl, F., Wallin, J. D., Fisher, J. W. : Hemodialysis and continuous am- bulatory peritoneal dialysis, effects on erythropoiesis in renal failure. Kidney Int., $25: 430$ $-436,1984$

22) Lamperi, S., Carozzi, S., Icardi, A. : Improvement of erythropoiesis in uremic patients on CAPD, Int. J. Artif. Organs 6 : 191-194, 1983.

23) Bergstroem, J., Fuerst, P. : Uremic toxins, Replacement of renal function by dialysis 2 nd ed. (ed. by Drukker, W., Parsons, F. M., Maher, J. F.) Chapter 19, pp 354-390, Martinus Nijhoff Publishers, 1983.

24) Moncrief, J.W., Popovich, R. P. : Peritoneal dialysis for a greater number of patients ?, Controversies in Nephrology I pp 35-44, Georgetown Univ., Nephrology Division, 1979.

25）大平整爾, 阿部憲司, 今 忠正：慢性腎不全症例に 対する CAPD の臨床評価。北海道医誌，59： 478-487, 1984. 